\title{
Sociodemographic characteristics of young people using internet cafés
}

\section{Internet kafelerdeki \\ gençlerin \\ sosyodemografik} özellikleri

\author{
Filiz O̊zsoy ${ }^{1}$, Muiberra KULU ${ }^{2}$
}

${ }^{1}$ Tokat Devlet Hastanesi, Psikiyatri Anabilim Dalı, Tokat, Türkiye

${ }^{2}$ Tokat Ruh Sağlığı ve Hastalıkları Hastanesi, Tokat, Türkiye

Corresponding author: Filiz Özsoy, MD, Tokat Devlet Hastanesi, Psikiyatri Anabilim Dalı, Tokat, Türkiye

E-mail: flzkoseoglu82@gmail.com

Received/Accepted: March 21, 2019 /June 25, 2019

Conflict of interest: There is not a conflict of interest.

\section{SUMMARY}

Objective: The internet is a major phenomenon of today's society since it gives easy access to information. Internet use is becoming increasingly widespread, and area of use has been expanding. Based on figures from the Turkish Statistical Institute, home internet access was $41.6 \%$ in 2010 and increased to $83.8 \%$ in 2018 . Despite increases in household internet access, use of internet cafés is also on the increase. The aim of the present study was to determine the sociodemographic characteristics of young people using internet cafés and the reasons why they prefer using internet cafes.

Method: The study was carried out on internet cafés registered by Tokat Health Provincial Directorate. Written consent was taken from participants, and sociodemographic data questionnaire prepared by the investigators was completed by all subjects.

Results: All participants and interviewed people were male. The average age of the participants was $20.1 \pm 2.34$. Forty-two of them (70\%) had home internet access, while $18(30 \%)$ did not. The main reason for using internet café was playing online games (42 participants, 70\%). The participants mentioned that they used internet cafés 2-30 days in a month and 1-16 hours on a day.

Conclusions: In the present study dealing with the sociodemographic data of young people using internet cafés, it was found that people younger than 24 years prefer using these cafes and they could spend a considerable amount of

time and money there. In addition, which web sites were visited and which online games were played by young people, how often and how long they used these public places were also questioned.

Keywords: Internet cafés, sociodemographic data, online game
Filiz Özsoy

Müberra Kulu

ORCID IDs of the authors: F.Ö. 0000-0002-5198-8827 M.K. 0000-0002-1402-2388

\section{ÖZET}

Amaç: İnternet, bilgiye ulaşmayı sağladığı için toplumu yakından ilgilendirmektedir. Her geçen gün internet kullanımı yaygınlaşmakta ve kullanım alanı da genişlemektedir. Türkiye İstatistik Kurumu 2018 Yılı Araştırma sonuçlarına göre; Türkiye'de 2010 yılında ev internet erişim imkanı \%41.6 iken 2018 yılında bu oran \%83.8'e kadar yükselmiştir. Ev içi internet erişim imkanları artmasına rağmen internet kafelere gitme oranı da artmaktadır. Biz çalışmamızda internet kafelere giden gençlerin sosyodemografik özelliklerini ve neden internet kafeleri tercih ettiklerini incelemeyi amaçladik. 
Yöntem: İl Sağlık Müdürlüğü’nce izin verilen internet kafelerde çalışmamız yürütüldü. Çalışmaya katılmayı kabul eden kişilerden yazılı onam alındı ve araştırmacılar tarafından düzenlenen sosyodemografik veri formu uygulandı.

Bulgular: Tüm katılımcılar ve görüşülen kişiler erkekti. Katılımcıların yaş ortalaması 20.1 2.34 idi. Katılımcılardan 42 (\%70) kişinin evinde internet erişimi var iken, 18 (\%30)'unun ise yoktu. Kişilerin geliş amaçları olarak ilk sırada 42 (\%70) kişi ile oyun oynamak yer almıştır. Katılımcılar bir ay içerisinde internet kafeye geldikleri gün sayısını 2-30 gün arasında değiştiğini ve gün içerisinde de 1-16 saat arasında internet kafede kaldıklarını bildirmişlerdir.

Sonuç: İnternet kafedeki gençlerin sosyodemografik verilerinin incelendiği çalışmamızda, internet kafeleri 24 yaş altı erkeklerin tercih ettiği, bu ortamlarda kişilerin uzun zaman ve para harcayabildikleri görüldü. Bu çalışmada kişilerin internet kafelerde hangi siteleri tercih ettikleri, çoğunlukla hangi oyunları oynadıkları, bir gün ve bir ay içerisinde ne kadar sıklıkla gittikleri gibi değişkenler sorgulanmıştır.

Anahtar sözcükler: İnternet kafeler, sosyodemografik veriler, internette oyun

\section{INTRODUCTION}

The internet, a world-wide communication network which gets increasingly larger, is a technology platform which has developed as a result of people's desire to store, share, and access easily to the produced information. Thanks to this information network, people can access to information in many areas in a fast, inexpensive, easy, and safe way ${ }^{1}$.

The number of people using the internet has been on the increase. Based on the surveys conducted by the Turkish Statistical Institute, $83.8 \%$ of homes in Turkey had internet access in 2018, which was $41.6 \%$ in 2010. Percentage of households using a computer was reported to be $59.6 \%$, while percentage of the ones using the internet was $72.9 \%$. In terms of gender, $68.6 \%$ of men use computer while $50.6 \%$ of women are a computer user. Survey results from household internet use; on the other hand, showed that $80.4 \%$ of men and $50.6 \%$ of women use the internet at home $^{2}$.

While internet and computer use are considered as useful means supporting the personal development of people such as obtaining knowledge, conducting research, solving problems and increasing creativity, their uncontrolled, unconscious, improper and overuse result in concerns and fears ${ }^{3,4}$. Internet cafés are favorite places offering internet access for people who have no internet access at their homes. Along with the general increase in internet use, a number of internet cafés and the average time people spend there are also increasing ${ }^{5}$. Studies conducted in Turkey showed that $86.4 \%$ of internet café users are men, and $37.8 \%$ of them are young people of 16-20 years of age ${ }^{6}$.

The aim of this study is to understand why internet cafes are preferred. For this purpose; we investigated the socio-demographic characteristics of internet café users such as age, gender, marital status, education level, economic status, and why they prefer to use internet cafes.

\section{MATERIAL AND METHODS}

The present study was approved by Tokat Gaziosmanpaşa University Non-invasive Local Ethics Committee and Tokat Health Provincial Directorate. The study was carried out in registered cafés in accordance with the Helsinki Declaration. Internet café users were informed about the study, and written consent was taken from the individuals willing to participate in the study. Individuals unwilling to participate, and individuals younger than 18 years of age were not included. The participants were given a sociodemographic data form prepared by the investigators.

Sociodemographic data form: In accordance with the clinical experience and information acquired from previous publication, as well as considering the aims of the study, a Sociodemographic and Clinical Data Form prepared by our team was applied to all participants. This form asked questions about age, marital status, education, living place, employment, and economic status of individuals. It was a semi-constructed form in which website and online preferences of internet café users and their reflections about internet cafes were questioned.

Statistical analyses: Descriptive statistical analyses were performed to obtain information about the general characteristics of participants. Data from continuous variables were expressed mean \pm standard deviation, while data from categorical variables were given as $\mathrm{n}(\%)$.

Qualitative variables were demographic data such as gender, age, education level, and socioeconomic status. Cross-table and chi-square tests were used to determine possible relationships between qualitative variables. $\mathrm{p}$ values less than 0.05 were considered significant. The SPSS for Windows 19 (Statistical Package for Social Sciences for Windows 19) statistical software has been used in the calculations. 


\section{RESULTS}

Two internet cafés registered by Tokat Health Provincial Directorate were visited different times. About 160 individuals were interviewed and informed about the study. Fifty-two of them were under 18 years of age and were excluded from the study, while 38 were excluded since they were not willing to participate and 10 were excluded since they did not complete the data scales given to them. Thus, the study included 60 individuals.

All participants and individuals interviewed were male. Age of the participants varied from 18 to 24 , and the mean age was $20.1 \pm 2.34$. In terms of education level, $14(23.33 \%)$ were high school students, 34 (56.66\%) were high school graduates, and $12(20 \%)$ were college graduates. For economic status, $20(33 \%)$ had a low level of income, while $16(26.66 \%)$ had moderate and 24 $(40 \%)$ had high-level income. Thirteen participants $(21.66 \%)$ had a job with regular income, eight $(13.33 \%)$ had a job with irregular income such as part-time jobs or seasonal works, and $35(58.33 \%)$ were students while four $(6.66 \%)$ were unemployed.

Fathers of two of the participants were deceased while the mother of one (1.66) was deceased. Parents of other participants were alive and living together. In terms of employment of parents, only fathers were working at households of 40 participants $(66.66 \%)$, only mothers were working at households of two participants (3.33\%), while both parents of 15 participants $(25 \%)$ were working and both parents of three participants (5\%) were unemployed.

Forty-two participants (70\%) had internet access at home while the home of $18(30 \%)$ did not. A number of visits to internet cafés by participants in a month ranged from 2 to 30 (average 13.41). Average daily time spent by them in internet cafés varied from 1 to 16 hours (average $4.86 \pm 4.73$ hours). Fifteen of the participants $(25 \%)$ reported that they visited cafés only at weekends and 23
(38.33\%) mentioned that they visited only on weekdays, while 22 of them (36.66\%) visited on both weekdays and at weekends. The average amount of money they spent in internet cafes ranged from 5 to 200 Turkish Liras (average 48.45 \pm 37.06$)$. Thirty-two participants $(53.33 \%)$ paid this by their pocket money, while $9(15 \%)$ asked it directly from their parents and 19 participants (31.66\%) spent the money they earned themselves.

The main purpose of using internet café was playing online games in 42 participants $(70 \%)$, followed by online chatting in $5(8.33 \%)$, listening to music in $5(8.33 \%)$, visiting various websites in $1(1.66 \%)$, preparing class homework in 1 $(1.66 \%)$, sending e-mail in $1(1.66 \%)$ and all of them in $5(8.33 \%)$.

The participants mentioned that they visited a few different websites. In terms of websites visited most by participants 24 of them (40\%) reported mentioned online game sites, nine $(15 \%)$ websites for movie watching, 6 (5\%) websites for chatting, three $(5 \%)$ web sites for sports/newspapers, two (3.33\%) websites for politics, eight $(13.33 \%)$ pornographic websites and one (1.66\%) scientific websites. (Participants visiting different websites mentioned here the one they most commonly visited.) Twenty-four participants reported that they visited all of the abovementioned types of websites. In terms of online games, strategy and action games were the most preferred ones by the participants.

When the reasons for preferring internet cafes were asked using options of "making use of leisure time", "enjoying the time spent in internet cafe", "feeling that their self-confidence is boosted by visiting an internet cafe" and "relaxing through going to an internet cafe", three participants $(5 \%)$ responded that they did not agree with any of the options, while 46 (76.66\%) responded that they agreed to some degree and 11 participants (18.33\%) strongly agreed. 
Table 1. Socio-demographic characteristics of internet café users

Age (Years)

Gender (Men/Women)

Educational level

High school student

High school graduate

College graduate

Socioeconomic status

Low

Moderate

High

Number of days with an internet visit in a month

Length of time (hours) spent on internet café

Amount of money (Turkish Liras) spent on internet café

Presence of internet access at home (Yes/No)
$20.1 \pm 2.34$

$60 / 0$

56.66

20.00

33.33

26.66

40

$13.41 \pm 9.11$

$4.86 \pm 4.73$

$48.45 \pm 37.06$

$70 / 30$

$92.85 / 7.14$

Type of home internet package (Limited/Unlimited)

Cross-table and Chi-square test has been used. The values shown in the table were shown as a percentage

$(\%)$.

Values given are averages and percentage.

\section{DISCUSSION}

Internet is a means of communication with huge benefits for our daily lives, but it also poses some threats such as being addictive. Especially teenagers could experience problems related to internet misuse or abuse. The present study investigated the sociodemographic characteristics of young people using internet cafés, websites preferred by these individuals, online games they played there and frequency their visits to internet cafés in a month and duration of time spent there on a day. All interviewed individuals, and consequently, all participants, were male. One such study revealed that of 387 young people using internet cafés 119 (30.74\%) were women while $268(69.25 \%)$ were men ${ }^{7}$. On the other hand, another study reported that $93 \%$ of internet café users were men ${ }^{8}$. A higher percentage of men in the present study as well as in the literature could be due to the facts that men participate in social life more and especially girls are subjected to higher protection and overseeing than boys are ${ }^{9,10}$. In terms of age distribution, it was found that the majority of internet café users were young people of 18-24 years of age. Most of the similar studies pointed to this age interval ${ }^{7,8}$. It was reported that students frequently use internet cafés to access the internet ${ }^{11}$. Similarly, students constituted the majority $(58.33 \%)$ of internet café users in the present study. In addition, considering the individuals who were excluded, it could be stated that this percentage could actually be higher.

Participants mentioned that they used the internet most for playing online games (70\%). Similarly, another study carried out to determine the purpose of children and teenagers in using internet found that playing online games was the leading purpose 3. Another study mentioned that men use the internet more frequently than women, and they do so mostly for entertainment and communication purposes. Use of internet for entertainment mainly involves playing online games followed by online chatting and listening to music ${ }^{12}$. Along with the advances in technology, the game concept has come to be perceived as video games, computer games, and mobile games played by mobile devices. These terms could be used interchangeably and are collectively referred to as "digital games" ${ }^{13}$. Their characteristics, such as allowing personal preferences, providing fun and their dynamic nature is making active interaction 
possible are among the reasons of preference for the target group. There are digital game platforms based on many different subject areas, such as training, advertising, entertainment, and publication ${ }^{14}$. Digital games could be classified based on a game platform, a number of players and player's consideration of the game. According to a classification made in 2008 , digital games could be classified as action/adventure, fighting, sports, simulation, strategy, educational and roleplaying games ${ }^{15}$. The present study also revealed that internet café users visited online game sites most (40\%). Strategy and action games were among the most preferred ones. A study found that men preferred exciting online games most on the internet in which they could perform strategic planning. The second most preferred online game type was strategy games, a game type which girls do not prefer at all ${ }^{13}$. Besides playing online games, internet café users in the present study mentioned other purposes of using internet cafés such as listening to music, online chatting, and accessing other websites for various purposes. These findings seem to be in line with the literature. It has been shown that young people use the internet more commonly for playing online games, online chatting, and listening to music $^{3,12}$.

The reason why internet café users preferred these places despite their unlimited internet access at their homes were investigated through questioning the preference for internet cafes in sociodemographic data form. Most individuals considered using internet cafés as a pastime activity. They reported to be happy and relaxed, and their self-confidence increased when they used internet cafés. In contrary to the reflections of individuals using internet cafés, it has been shown in the literature that the digital world makes people lonely and isolates them socially 16,19. In fact, one study found higher anxiety and depression levels in connection with internet overuse ${ }^{17}$. In another study conducted on college students, Internet Addiction Scale points, and Beck Depression Scale points of students were found to be correlated ${ }^{18}$. In children, on the other hand, positive correlations were found between computer game addiction and alexithymia and social anxiety levels ${ }^{19}$.

Findings of the present study should be evaluated considering some limitations pertaining to it. First, the sample size was not large. Other limitations were that the study included only male participants, and only a limited number of internet cafés were sampled. These limitations prevent the generalization of our findings. More advanced studies in which larger sample populations are sampled from larger number of internet cafés are needed to make generalizations.

\section{CONCLUSION}

In the present study, sociodemographic characteristics and reasons of individuals for preferring internet cafés were investigated through sampling the users of some internet cafés. Although all internet café users were targeted for the study, all interviewed individuals were men. A great majority of internet café users preferred visiting online game sites, and strategy and action games were among their favorites.

Along with the increasing use of computers and the internet, interest in internet cafés is also on the rise. Long term uncontrolled computer and internet use could negatively affect the physical, psychological, and mental health and life of individuals. While providing appropriate, efficient and fruitful internet access to individuals (child/young or adult), their security should also be taken into account. Therefore, involved authorities and institutions should attach more importance to this topic and take necessary precautions.

\section{REFERENCES}

1. Bilgisayar ve teknoloji rehberi. Alınma tarihi Eylül 2010 http://www.bilisimterimleri.com/bilgisaya r_bilgisi/bilgi/12.

2. 2. Türkiye İstatistik Kurumu (TÜIKK). 2018 Yılı Hane halkı Bilişim Teknolojileri Kullanımı Araştırması. Tarih: 08/08/2019 Say1: 27819, //http://www.tuik.gov.tr//TRT//Teleteks:5 90/; 2019.

3. Cömert IT, Kayıran SM. Çocuk ve ergenlerde internet kullanımı. Çocuk Derg, 2010; 10(4):166-170.

4. Kerberg CS. Problem and pathological gambling among college athletes, Ann Clin Psychiatry, 2005;17(4):43-7.

5. Can Y. İnternet Kafeye Gitme Alışkanlığının Öğrencilerin Sosyal Çevreyle Olan İlişkilerine Etkisi. HÜTAD, 2008(8); 55-68.

6. Taşpınar M, Gümüş Ç. Ülkemizde İnternet Kafelerin Ortam ve Kullanic1 Profili: Bilgi Toplumu Açısından Değerlendirme. E-Sos Der, 2005;4: 8093.

7. Demir Y, Kutlu M. Adolescents and Internet Cafes. Journal of the Faculty of Education, 2018; 19(3): 452-460. 
8. Mermer F. Bursa-merkez yerleşiminde internet kafelerde internet kullanımı ve kullanıcıların sosyodemografik analizi: Osmangazi örneği. T.C. Uludağ Üniversitesi Sosyal Bilimler Enstitüsü Sosyoloji Anabilim Dalı. Yayınlanmamış Yüksek Lisans Tezi, Bursa, 2004.

9. Oral G. Adli Psikiyatri. (Editör: Soysal Z, Çakalır C). Adli Tıp Cilt 3. İstanbul: İstanbul Üniversitesi Basımevi ve Film Merkezi, 1999: s.1589-395.

10. Tamer H, Açıksarı Ö, Keten A, Karanfil R, Avşar A. Kahramanmaraş ilinde suça sürüklenen çocukların sosyodemografik özellikleri. Adli T1p Derg, 2014; 115-120.

11. Odabaşı HF, Kabakçı I, Çoklar AN. İnternet, çocuk ve aile, 2nd ed. Ankara Nobel Basımevi, 2007.

12. Bayraktar F, Gün Z. The incidence and correlates of internet usage among adolescents in Northern Cyprus. Cyber Psychology Behav, 2007;10(2):191-7.

13. Pala FK, Erdem M. Dijital Oyun Tercihi ve Oyun Tercih Nedeni ile Cinsiyet, Sinıf Düzeyi ve Öğrenme Stili Arasındaki İlişkiler Üzerine Bir Çalışma. Ahi Evran Üniversitesi Eğitim Fakül Derg, 2010;12(2):53-71.

14. Yavuz E, Tarlakazan ÖÜE. Üniversite Öğrencilerinin Mobil Oyun Profili ve Oynama Alışkanlıkları. AÇÜ Uluslararası Sosyal Bilimler Derg, 2018; 4 (2): 149163.
15. Kaya AB. Çevrimiçi Oyun Bağımlılığı Ölçeğinin Geliştirilmesi: Geçerlik ve Güvenirlik Çalışması. Tokat: Yayınlanmamış Yüksek Lisans Tezi. Gaziosmanpaşa Üniversitesi Eğitim Bilimleri Enstitüsü, 2013.

16. Demirbilek M, Koç D. Video Oyunlarının ve Video Oyun Kafelerin Birey Sağglığına Etkileri: Nitel Bir Araştırma. Conference: Akademik Bilişim, 2016.

17. Çam HH, Nur N. Adölesanlarda internet bağımlılığı prevalansı ile psikopatolojik semptomlar ve obezite arasındaki ilişkinin incelenmesi. TAF Preventive Medicine Bulletin, 2015; 14(3): 181-188.

18. Gunay O, Ozturk A, Arslantas EE, Sevinc N. Erciyes Üniversitesi öğrencilerinde İnternet bağımlılığı ve depresyon düzeyleri. Dusunen Adam: J Psychiatry and Neurological Sci, 2018;31:79-88.

19. Taş İ, Güneş Z. 8-12 yaş arası çocuklarda bilgisayar oyun bağımlılığı, aleksitimi, sosyal anksiyete, yaş ve cinsiyetin incelenmesi. Klinik Psikiyatri; 2019:22. 